DOI: https://doi.org/10.18371/fp.3(39).2020.215162

УДК 316.346.2-055.2:334.74

\title{
СУЧАСНІ ТРЕНДИ РОЗВИТКУ ЖІНОЧОГО ПІДПРИЄМНИЦТВА В УКРАїН
}

\author{
ТАНКЛЕВСЬКА Наталія Станіславівна \\ доктор економічних наук, професор, \\ завідувач кафедри економіки та фінансів \\ ДВНЗ «Херсонський державний аграрний університет» \\ ORCID ID: http://orcid.org/0000-0003-2906-4051 \\ e-mail:ntanklevska@gmail.com
}

\begin{abstract}
Анотація. Визначено, що сучасний етап розвитку украӥнського суспільства, характеризується активністю жжінокпідприємниць, які ефективно конкурують 3 підприємиями-чоловіками. Систематизовано основні бар'єри на шляху розвитку жіночого підприємництва(економічні, бюрократичні, освітні, культурні). Проаналізовано різноманітні програми підтримки жіночого підnриємництва та лідерства в Україні. Визначено ключові елементи активізачії розвитку жіночого підприємництва, надання вільного доступу до якісних інструментів їх фінансово-кредитної підтримки; покращчення інформачійного та кадрового забезпечення бізнесу; отримання нових знань у розвитку онлайн-каналів, виходу на нові сегменти ринку в умовах постпандемії.
\end{abstract}

Ключові слова: підприємництво, жіноче підприємництво, бізнес, фінансування, розвиток, ринок, освіта, підтримка, постпандемія.

Постановка проблеми. Основним трендом останніх років в Україні $€$ популяризації теми розвитку жіночого підприємництва. Сьогодні дінамічно збільшується відсоток жінок, які відкривають власний бізнес, зокрема 3 надання послуг у сфері краси та здо-
Аннотация. Определено, что современный этап развития украинского общества, характеризуется активностью женщинпредпринимательнии, которые эфрфективно конкурируют с предпринимателямимужчинами. Систематизированы основные барьеры на пути развития женского предпринимательства( экономические, бюрократические, образовательные, культурне). Проанализировань различные программь поддержки женского предпринимательства и лидерства в Украине. Определень ключевые элементы активизачии развития женского предпринимательства, предоставление свободного доступа к качественным инструментов их финансово-кредитной поддержки; улучшение информаџионного и кадрового обеспечения бизнеса; получение новых знаний в развитии онлайн-каналов, выхода на новые сегменты рынка в условиях постпандемии.

Ключевые слова: предпринимательство, женское предпринимательство, бизнес, финансирование, развитие, рынок, образование, поддержка, постпандемия.

ров'я, консалтингу, IT і роздрібної торгівлі. Підприємництво - це вкрай важливий елемент в економічній системі сучасного суспільства, враховуючи важливість самозайнятості населення, внеску малого і середнього бізнесу в ВВП України - 55\%, зокрема 
малого - 16\% ВВП [1]. При цьому, підприємницька сфера виступає важливим суб'єктом економічної діяльності, від результатів якої залежить як добробут окремого суб'єкта, так й населення країни в цілому. Сучасний етап розвитку українського суспільства, характеризується активністю жінокпідприємниць, які ефективно конкурують 3 підприємцями чоловіками. Враховуючи те, що діяльність підприємця вимагає від нього повної віддачі сил і часу, жінки життєво необхідно тримати баланс між свою кар'єрою та сім'єю й особистим життям, в той час як чоловіки, зазвичай, зосереджені на своій кар'єрі. 3 іншого боку, саме особистість та інтуїція жінок сприяють розширенню такого підприємництва, як нової сфери, де можна повністю реалізувати себе, зрозуміти і осягнути свій рівень. Тому саме сьогодні актуальними залишаються питання визначення особливостей розвитку жіночого підприємництва в Україні, виявлення його проблем та шляхів їх подолання.

Аналіз останніх досліджень та публікацій. Питання розвитку жіночого підприємництва активно досліджують зарубіжні й вітчизняні вчені, зокрема Д. Айгу, Д. Гечеварія, Г.М. Карделла, Б.Р. Хернандез-Санчес, Дж.С. Санчес-Гарсія, Т. Журженко, Н. Ісакова, О. Коломієць, Н. Лавриненко, Н. Олійник, О. Стрельник, В. Суковата, В. Шацька

Так, на думку іспанських вчених [2] жінки-підприємці представляють найбільш швидкозростаючу категорію підприємництва у всьому світі i, особливо в останні роки, привертають увагу багатьох науковців. Згідно до останніх зарубіжних досліджень, жінки можуть зробити значний внесок у підприємницьку діяльність та економічний розвиток $з$ точки зору створення нових робочих місць та збільшення валовий внутрішній продукт, що позитивно впливає на підвищення добробуту домогосподарств та зменшенню соціальної ізоляції [3, 4]. При цьому, враховуючі український досвід, Н. Олійник, стверджує, що в сфері бізнесу жінки мають менше можливостей реалізувати свою активність через наявність інституційних бар'єрів та перешкод різного характеру і це негативно впливає на діяльність, і кар'єрні досягнення жінок, тим самим понижуючи їх самооцінку та прагнення до самореалізації. I хоча жінкипідприємниці в Україні складають чверть власників підприємств, вони володіють в основному малими підприємствами. Важливим у сучасних українських реаліях $є$ сприяти розвиткові жіночого підприємництва, адже підприємництво пробуджує в жінок ініціативу до ділової активності та економічної діяльності [5].

Таким чином, можна стверджувати, що проблематика активізації розвитку жіночого підприємництва продовжує залишатися актуальною й значущою.

Метою даного дослідження є визначення специфіки розвитку жіночого підприємництва в Україні, а також виявлення основних перешкод та векторів активізації його розвитку.

Виклад основного матеріалу. Слід підкреслити, що саме розвиток жіночого підприємництва $є$ однією з важливих тенденцій функціонування сучасного ринку праці, як у розвинутих країнах, так і в інших країнах. Результати першого дослідження Index of Women Entrepreneurs (Індекс жінокпідприємців) від Mastercard свідчать, що індекс жінок-підприємців $є$ най- 
вищий на розвинених ринках. Перше місце посідає Нова Зеландія, друге Канада і третє - Сполучені Штати Америки. Ці країни мають найбільш сприятливі умови для розвитку жіночого підприємництва, зокрема активні спільноти власників малого та середнього бізнесу, високу якість регулювання та легкість ведення бізнесу. Цікавим $є$ те, що в країнах з низьким рівнем доходу, зокрема Уганда, Бангладеш та В'єтнам, є велика частка жінок-підприємців, які в більшості випадків розпочинають підприємницьку діяльність через матеріальні потреби, а не через сприятливі можливості на ринку [5]. Як свідчить досвід 3 розвитку жіночого підприємництва у США, американські жінки започатковують нові підприємства у півтора раза частіше, ніж чоловіки. На сьогодні саме жінки очолюють вже понад третину американських компаній i ïx кількість постійно зростає. Наприклад, підприємець Ніколь Деш відкрила заклад, який поєднує садочок та офіс, що дозволило не лише отримати дохід, а й допомогти жінкам керувати своїм бізнесом, в той час як їхні діти під наглядом. Також Сейдж Лавін, автор книги «Жінки рушій бізнесу» стверджує, що щодня жінки в США започатковують 1200 компаній 3 обігом понад трильйон доларів на рік [6].

Сьогодні в Україні жінки змушені не тільки масово змінювати свій соціальний та професійний статус, але в більшості випадків його знижувати, стаючи безробітними, вони перекваліфіковуються, як правило, на інші професії і використовуючи форми зайнятості, які не потребують ні освіти, ні накопичених професійних знань. Жінки беруть участь у перетвореннях національної економіки, змінюють форми трудової активності. Основне соціальне протиріччя, що склалося в сфері зайнятості жінок, полягає в тому, що, з одного боку, ринкова модель дозволяє вільно розвиватися жіночій економічній ініціативі, самостійності і незалежності у виборі форм зайнятості, з іншого боку, в умовах переходу до ринку, принципово відмінних від сформованих за радянських часів норм, установок трудової поведінки, жінки виявляються менш готові до вільної, ініціативної діяльності, менш адаптовані, ніж чоловіки. При цьому, спостерігається тенденція збільшення кількості жінок, які обирають дрібний бізнес. Саме звернення до дрібної комерційної діяльності для переважної більшості жінок вимушене, ніяк не пов'язане 3 колишньою професійною діяльністю; жінки не просто змінюють свій соціальний та професійний статус $[7,8]$. Враховуючи існуючі економічні проблеми, умови пандемії та низькі соціальні гарантії з боку держави, саме підприємницька діяльність для багатьох жінок, особливо у сільській місцевості, $\epsilon$ єдиною альтернативою пасивному очікуванню допомоги від держави [7]. Слід підкреслити, що основним рушійним мотивом прийняття такого рішення стає почуття відповідальності за своїх близьких, яке, залишає осторонь якості, які зазвичай стримують підприємницьку активність жінок.

Основні перешкоди на шляху до розвитку жіночого підприємництва в країнах 3 перехідною економікою можна розділити на три види (табл.1).

Існують різні бар'єри розвитку підприємництва для американських i українських жінок, враховуючи ймо- 
вірні міжкультурні та ментальні від-

мінності.

Таблиця 1

Основні перешкоди на шляху до розвитку жіночого підприємництва в Україні

\begin{tabular}{|c|c|c|}
\hline № & Вид бар`єру & Сутність існуючих перешкод \\
\hline 1 & Економічні & $\begin{array}{l}\text { недостатній або відсутність стартового капіталу; складність } \\
\text { доступу до фінансових ресурсів; конкуренція з боку великих } \\
\text { вітчизняних або зарубіжних компаній; несприятлива державна } \\
\text { політика по відношенню до розвитку бізнесу; обмежений вихід } \\
\text { на закордонні ринки через невідповідності стандартам, встано- } \\
\text { вленим більш розвиненими країнами. }\end{array}$ \\
\hline 2 & $\begin{array}{l}\text { Бюрократичні й } \\
\text { юридичні }\end{array}$ & $\begin{array}{l}\text { нечіткі і часто мінливі юридичні положення, що стосуються } \\
\text { відкриття та розвитку бізнесу; відсутність підтримки з боку } \\
\text { уряду. }\end{array}$ \\
\hline 3 & Освітні & $\begin{array}{l}\text { обмежений доступ до консультаційних послуг центрів для } \\
\text { тих, хто бажає відкрити свій бізнес або просувати його; обме- } \\
\text { жений доступ до знань та інформації; висока вартість профе- } \\
\text { сійних тренінгів, що надаються на ринку; обмежені можливості } \\
\text { в постійному навчанні. }\end{array}$ \\
\hline 4 & $\begin{array}{l}\text { Культурні й ген- } \\
\text { дерні }\end{array}$ & $\begin{array}{l}\text { балансування роботи та сімейного дозвілля; неповне прийн- } \\
\text { яття суспільством приватної економічної діяльності; недостат- } \\
\text { ньо шанобливе ставлення до підприємців; відсутність традицій, } \\
\text { що стосуються навчання людей підприємницької діяльності; } \\
\text { побоювання з приводу майбутніх змін; гендерна дискримінація } \\
\text { в бізнесі; домінування патріархальних цінностей. }\end{array}$ \\
\hline
\end{tabular}

Джерело: згруповано автором на основі $[5,7,9]$.

Головними перешкодами на шляху ефективного розвитку жіночого підприємництва в Україні опитані респондентки вважають: бюрократія урядових органів влади $(77 \%$ респонденток); відсутність державної допомоги (66\%); недостатність фінансування для запатентування бізнесу (60\%). Менше ніж 10\% респонденток відмітили, що вони не перетиналися із державною бюрократією або що це неважливо. Щодо опитування «Я маю змогу оплатити потрібне фінансування для власного бізнесу», тільки 13\% були спроможні знайти необхідні кошти. Більшість респонденток зайшли головну частку фінансування бізнесу самотужки $(40 \%)[10]$.

Також, основною проблемою нерозвиненості жіночого підприємництва в Україні, на думку заступника голови
Офісу Президента України Юлії Ковалів, є ментальність у культурі та вихованні. Таку думку вона висловила у рамках діалогової зустрічі бізнесу та влади платформи SheExports на тему: «Розширення економічних можливостей жінок та розвиток жіночого підприємництва в Україні». «Більша частина працездатного населення виросла в радянську та пострадянську епоху. Тоді у вихованні були закладені певні штампи: дівчатка ходили в садочок в рожевих платтях і гралися ляльками, а хлопчики будували заводи, водили машини і хотіли стати космонавтами. Такий розподіл обов'язків власне і відобразився на моделі поведінки в подальшому цих дівчат та хлопців. Тому, в першу чергу, варто говорити про «дірки» у вихованні та освіті жінок», - говорить Ю. Ковалів. 
Експерт акцентує, що в Україні уже третій рік поспіль запускається програма нової школи, в рамках якої у дівчаток формують гендерно правильні навички, вони займаються програмуванням, грають у шахи та інші інтелектуальні ігри [11].

До соціальних передумов, що носять зовнішній характер і стримує розвиток жіночого підприємництва, слід перш за все віднести загальні проблеми, пов'язані $з$ положенням жінок в сфері праці. В основі цих проблем лежить домінування патріархальних цінностей, які в умовах переходу до ринкових відносин, не дивлячись на демократизацію суспільства в цілому, тільки посилилися. Основними показниками такого становища жінок $є$ : соціальна дискримінація жінок (при прийомі і звільненні, при оплаті праці тощо); існування стереотипів рольових функцій жінок, в тому числі і в сфері праці; деякі форми соціального захисту жінок, що мають характер обмежень у сфері праці $[5,7]$.

Причинами неповної зайнятості жінок $€$ різними: від необов'язковості трудової діяльності й сприймання ii радше як засобу самореалізації - до змушеного поєднання кількох видів діяльності, використання будь-якої можливості заробітку. В інших країнах світу серед частково зайнятих також переважають жінки. В Україні та світі досі існує нерівна оплата за виконання однієї й тієї самої роботи жінками та чоловіками. Відповідно до результатів опитування респондентів 3 різних країн, які наведені у звіті Світового економічного форуму, в Україні ця різниця оцінюється на рівні 0,71 за шкалою від 0 до 1 . У багатьох європейських країнах ситуація з гендерною рівністю в оплаті праці ще складніша. У Нідерландах та Німеччині відповідний показник становить 0,68 , Великобританії - 0,67, Польщі та Росії - 0,55 і 0,65 відповідно [12].

Необхідність поєднувати бізнес та домашні клопоти є суттєвою перешкодою приходу жінок у бізнес, джерелом формування комплексу провини перед родиною та дітьми, причиною родинних сварок через нерівномірний розподіл домашніх обов'язків та їх неналежне виконання. Слід, щоправда, зауважити, що і для жінки, найманого працівника, життєва ситуація часто складається подібним чином. Намагання ж успішно поєднувати усі види діяльності можуть спричинити хронічну перевтому, виснаження, стреси, хвороби. Проте, бажання забезпечити своїм дітям можливості для розвитку, добробут, гарний старт кар'єри $\epsilon$ могутнім стимулом для жінки розпочати власну справу та залучити родину до бізнесу. Родинний бізнес - це найбільш поширена форма організації підприємництва у світі. В окремих країнах сімейні компанії становлять понад 70\% загального числа усіх підприємств. Fiat, Siemens, L'Oreal, BMW, Samsung, Columbia Sportswear Company - приклади найбільш успішних сімейних компаній. Сімейна справа згуртовує родину. Між іï членами $є$ довіра, чого важко досягти 3 найманими працівниками [13].

На основі опитування жінокпідприємниць із 23 регіонів України було виявлено таку специфіку: більшість опитаних жінок прийшли в бізнес з вимушених причин; багато 3 них не радили б молодим жінкам розпочинати свій бізнес зараз, тому що умови змінилися не на краще, однак, ніхто не пошкодував про свій вибір; перешко- 
дами у веденні малого і середнього бізнесу жінками було визнано хабарництво, необхідність мати особисті зв'язки у «владних верхівках», відсутність державної підтримки, нестача кваліфікованого персоналу та труднощі, пов'язані 3 його пошуком; у процесі обробки інтерв'ю з українськими бізнес-леді у американських дослідників склалося враження, що опитувані були схильні до свідомого заниження самооцінки; дослідники зазначили складність у підборі кандидаток на інтерв'ю, якими мали бути незалежні жінки-підприємниці, а також констатували низький рівень довіри та обережність у спілкуванні, зокрема відмови у телефонному спілкуванні, незважаючи на вжиті заходи щодо етичного захисту учасниць проекту [10].

У аналітичному дослідженні «Інклюзивний розвиток бізнесу: жіноче підприємництво» зазначається, що ключовою проблемою, яка гальмує розвиток підприємництва в країнах Східної Європи, є доступ бізнесу до кредитування. Не зважаючи на те, що загалом у світі жінки в 1,5 раза частіше, ніж чоловіки, відкривають підприємства, проте їхній стартовий капітал - у 6 разів менший [12]. В цьому питанні Україна не є винятком. Жінкам набагато складніше отримати кредит, тому що вони мають менше ресурсів, які можуть слугувати заставою. У Звіті також йдеться про те, що жінки зазвичай отримують короткострокові кредити під вищі відсоткові ставки. Відсутність стартового капіталу - серйозна проблема для українок, які бажають розпочати свою справу. Інвестори та кредитори неохоче дають жінкам кошти, а наші співвітчизниці, своєю чергою, неохоче їх беруть, надаючи перевагу самофінансуванню через вкрай невигідні умови, які пропонуються банками $[6,12]$.

Соціальний портрет українських підприємниць формується під впливом певних факторів, серед яких можна виділити дві великі групи: трансформаційні та соціально-культурні фактори. До першого належать чинники, пов'язані з трансформацією, які переживає українське суспільство.

Розпочавшись 3 політики, трансформація зачепила та подекуди докорінно змінила й інші сфери суспільного буття: позначилася на економіці, культурі, побуті, цінностях, світогляді, поведінці [5]. Водночас, усвідомлюючи роль жінок як трудових ресурсів та потенційних суб'єктів підприємницької ініціативи, в умовах зростання споживання та підвищення соціальних стандартів сучасне суспільство не готове повернутися до гендерного розподілу ролей згідно з традиційною патріархальною моделлю. Іншою стороною трансформації $\epsilon$ пошук додаткових ресурсів та можливостей розвитку, зокрема, шляхом перегляду ролі жінок у суспільстві, стимулювання їхньої економічної активності, визнання традиційних поглядів стереотипами з подальшою відмовою від них, створення нових моделей поведінки жінок, які б схвалювалися суспільством.

Сьогодні в Україні існує безліч різноманітних програм підтримки жіночого підприємництва. Так, громадські організації, державні інституції та різні міжнародні фонди приймають активну участь у розвитку і популярізації жіночого підприємництва. Так, 11 березня 2020 року заступник міністра цифрової трансформації з питань євроінтеграції Валерія Іонан провела ді- 
алогову зустріч із бізнесом щодо розвитку жіночого підприємництва. Організатором події виступила \#SheExports - платформа підтримки жінок-підприємниць. Серія діалогових зустрічей бізнесу та влади на тему «Розширення економічних можливостей жінок та розвиток жіночого підприємництва в Україні» реалізується Deutsche Gesellschaft für Internationale Zusammenarbeit (GIZ) $\mathrm{GmbH}$ за підтримки уряду Німеччини в рамках проєкту «Підтримка рамкових умов для торгівлі в Україні». Під час зустрічі була оприлюднена наступна статистика:

- потрібно 257 років, щоб вирівняти оплату праці між чоловіками і жінками, якщо ми рухатимемось зі швидкістю останніх 5 років;

- жінки задіяні в неоплатній хатнійсімейній роботі 4,4 години, а чоловіки 1,7 годин;

- серед 100 найбагатших людей україни лише три жінки;

- тільки 6\% бізнесів керують жінки [14].

Сьогодні в Україні запроваджено масштабний національний проєкт Мінцифри Дія.Бізнес. із розвитку підприємництва, який має дві складові: онлайн-платформу для підприємців і офлайн-складову - в різних регіонах України планується відкрити центри підтримки та хаби для підприємців. Окрім консультацій, у консалтингових зонах підприємці зможуть представити свій продукт іншим підприємцям і отримати зворотний зв'язок, пройти освітні програми та отримати додаткові послуги. Даний проект допомогає збільшити появу нових бізнесів у регіонах і кількість робочих місць, сприятиме розвитку трансформації малого бізнесу в серед- ній і виходу українських підприємців на міжнародні ринки [14].

Також, вагомий внесок у підтримку жінок-підприємниць здійснює «Інститут партнерства та сталого розвитку», зокрема через проект «Жіноче лідерство та підприємництво». Так, створено Inspiring Women Academy - Жінки, які надихають, захоплюють та ставлять перед собою високі цілі! Академія покликана допомагати українським жінкам та дівчатам розкрити свій лідерський потенціал та стати успішними бізнес-леді. В рамках комплексної програми 50 учасниць 3 різних регіонів України дізнались як започаткувати власну справу. Крім цього, Інститут щорічно проводить міжнародний бізнес-форум «БізнесWOMAN», метою якого $\epsilon$ консолідація жінок бізнесу, політики та соціальної сфери задля налагодження тісної співпраці, обміну досвідом, репрезентації України в світі та сприяння розвитку малого і середнього бізнеcy [15].

Слід відзначити, що світова пандемія та економічні наслідки карантинних заходів посилили та прискорили тенденції, які поступово розвивались останні роки, особливо щодо навчання та переходу в онлайн. Згідно 3 Дослідженням ведення бізнесу серед жінок-підприємниць, проведеним CBR для Visa у квітні-травні 2020 року, $64 \%$ опитаних власниць бізнесу готові до хоча $б$ часткового переведення свого бізнесу в онлайн, проте мають сумніви, чи вистачить їм для цього знань та ресурсів. При цьому $85 \%$ жінок прагнуть додаткового навчання. Серед найбільш затребуваних тем: як адаптуватися до нових реалій, як пережити кризу, пов'язану 3 пандемією, та як розвивати свій бізнес 
онлайн. Це свідчить про те, що жіночий бізнес поступово переходить у новий етап та починає свій стрімкий розвиток, який потребує ефективних практичних інструментів та сучасних знань для переходу на якісно нові рівні [16].

Пошук нових знань та інструментів через додаткове навчання та успішні приклади інших жінок-підприємниць підсилюють цю тенденцію та стрімко покращують показники жіночого підприємництва в Україні. Дослідження показує, що жінки-підприємниці відрізняються невпинною жагою до навчання $-85 \%$ жінок зацікавлені в додатковому розвитку через бізнес воркшопи. Якщо молоді власниці бізнесу зазвичай роблять акцент у навчанні на бізнес-стратегії, фінансовій та юридичній організації, то більш старші жінки-підприємниці зосереджують свою увагу на веденні та розширенні бізнесу, особливо в онлайн форматі. Із поступовим переходом в онлайн, жінки все частіше шукають платформи та ресурси для ознайомлення та вивчення таких тем як розвиток онлайн-бізнесу, механіка онлайн-продажів та просування в Інтернеті за допомогою соціальних мереж. Крім того, 69\% жінок-підприємниць надають перевагу онлайн-навчанню[16].

Непередбачувана пандемія та економічні наслідки, як ефект сніжної кулі, винесли на порядок денний нові питання та виклики. Результати дослідження яскраво підтверджують, що більший відсоток жіночого бізнесу постраждав в період пандемії COVID19: $38 \%$ скоротили свою дохідність, а 52\% - взагалі вимушені були зупинити діяльність. Найбільше постраждали сфера офлайн торгівлі, бізнеси в невеликих містах та бізнеси власниць більш старшого віку. Такий розвиток подій підвищує потребу власниць бізнесу різного масштабу до пошуку інструментів для адаптації та подальшого розвитку своєї справи. Незважаючи на те, що $41 \%$ жінокпідприємниць продає свої товари та послуги через Інтернет, вони значною мірою потребують знань у розвитку онлайн-каналів, виходу на нові сегменти та пошук додаткового фінансування [16].

Таким чином, вдосконалення розвитку жіночого підприємництва слід здійснювати саме в тих напрямках, де воно має беззаперечні переваги, враховує специфічні «жіночі» особливості поведінки, психіки, менталітету тощо. При цьому, непотрібно йти в напряму врівноваження сфер бізнес-діяльності жінок i чоловіків. Жіноче підприємництво саме по собі $\epsilon$ вагомим фактором еволюції національної економіки, сприяє іï стабілізації і динамічному зростанню. Тому, серед ключових елементів активізації розвитку жіночого підприємництва слід відзначити: впровадження дієвих законодавчонормативних актів, спрямованих на стимулювання відкриття нового бізнесу жінками; надання вільного доступу до якісних інструментів фінансовокредитної підтримки жіночого підприємництва; покращення інформаційного та кадрового забезпечення бізнесу.

Висновки. Отже, сучасне підприємництво є дуже важливим елементом в економічній системі України, який характеризується значною активністю жінок-підприємниць ефективно конкуруючих з підприємцями чоловіками. 3'ясовано, що індекс жінокпідприємців $є$ найвищий у розвинутих 
країнах, що обумовлено створенням сприятливих умов для розвитку жіночого підприємництва, а в країнах, що розвиваються, більшість жінок розпочинають підприємницьку діяльність через свої матеріальні потреби, що в більшості випадків відбувається й в Україні. На шляху розвитку жіночого підприємництва стоїть багато перешкод починючи з економічних та бюрократичних бар'єрів, закінчуючи соціальними, освітніми, культурними й гендерними. Для популяризації жіночого підприємництва в Україні існує безліч різноманітних програм його підтримки, зокрема громадські організації, державні інституції та різні міжнародні фонди приймають активну участь у розвитку жіночого підприємництва і лідерства. Також, виявлено, що серед ключових елементів активізації розвитку жіночого підприємництва слід відзначити: впровадження дієвих законодавчо-нормативних актів, спрямованих на стимулювання відкриття нового бізнесу жінками; надання вільного доступу до якісних інструментів фінансово-кредитної підтримки жіночого підприємництва; покращення інформаційного та кадрового забезпечення бізнесу; отримання нових знань у розвитку онлайн-каналів, виходу на нові сегменти ринку в умовах постпандемії.

\section{Список використаної літератури}

1. Денис Шемякін. Новини УНIAH. URL : https://www.unian.ua/ economics/finance/10596576-maliy-ta-seredniy-biznes-v-ukrajini-daye-55-vvpkabmin.html (дата звернення: 20.08.2020).

2. Cardella G. M., Hernández-Sánchez B. R., Sánchez-García J. C. (2020) Women Entrepreneurship : A Systematic Review to Outline the Boundaries of Scientific Literature. Front. Psychol. 11:1557. doi: 10.3389/fpsyg.2020.01557.

3. Hechevarría D., Bullough A., Brush C., Edelman L. High-growth women's entrepreneurship: fueling social and economic development. J. Small Business Managem. 2019. Vol. 57, Iss. 1. P. 5-13. doi: 10.1111/jsbm.12503.

4. Ayogu D. U., Agu E. O. Assessment of the contribution of women entrepreneur towards entrepreneurship development in Nigeria. Intern. J. Curr. Res. Acad. Rev. 2015. Vol. 3 (10), P. 190-207. URL : http://www.ijcrar.com/vol310/Ayogu,\%20Deborah\%20U.\%20and\%20Agu,\%20Everistus\%20Ogadimma2.pdf.

5. Індекс жінок-підприємців від Mastercard виявив умови, необхідні для розвитку жіночого підприємництва. Mastercard : веб-сайт. URL : https://newsroom.mastercard.com/ eu/uk/news-briefs/index-zhinokpidpryiemciv-vidmastercard-vyiav/ (дата звернення: 22.08.2020). 
6. Жінки-підприємці - нова рушійна сила на ринку праці у США. Голос Америки. VOA, Inc. : веб-сайт. URL : https://ukrainian.voanews.com/a/women-inbusiness-mothers/4015787.html_(дата звернення: 22.08.2020).

7. Валерія Шатська. Жіноче підприємництво в Україні: тенденції, проблеми, перспективи. Business Law Electronic Resource : веб-сайт. URL : https://www.businesslaw.org.ua/jinoch-pidpryemnyctvo-v-ukraini/_(дата звернення: 22.08.2020).

8. Hrubá Renata, Tanklevska Natalie S. Relationship between the knowledge economy and the education system in the context of intercultural communication. Central and Eastern Europe in the Changing Business Environment, May, 2018, p. 106-117.

9. Tanklevska N., Miroshnichenko V. Theoretical basis of managing of enterprises` financial potential on the basis of anti-crisis management. Agricultural and Recourse Economics: International Scientific E-Journal. 2019. № 2. Vol. 5. p. 51-61.

10. Дослідження «Жіноче підприємництво України : кілька питань». Management.com.ua : веб-сайт. URL : http://www.management.com.ua/ interview/int361.html_(дата звернення: 22.08.2020).

11. Юлія Ковалів. Як стимулювати жіноче підприємництво. AgroPortal : вебсайт. URL : https://agroportal.ua/ua/views/mnenie-eksperta/kak-stimulirovatzhenskoe-predprinimatelstvo-v-ukraine/(дата звернення: 22.08.2020).

12. Смаль В. Інклюзивний розвиток бізнесу : жіноче підприємництво. Київ, 2018. 132 c. URL : https://decentralization.gov.ua/uploads/library/ file/490/Woman_Business_PLEDDG_2019.pdf (дата звернення: 25.08.2020).

13. Олійник Н. Ю. Жіноче підприємництво в Україні: особливості та перспективи. Фінансовий простір. 2015. № 2. С. 390-396.

14. Проєкт Міністерства та Комітету цифрової трансформації України. Дія. Бізнес. Міністерство та Комітет цифрової трансформації України : веб-сайт. URL : https://business.diia.gov.ua https://thedigital.gov.ua/news/na-platformidiyabiznes-zyavitsya-rozdil-pro-zhinoche-pidpriemnitstvo (дата звернення: 25.08.2020).

15. Проєкт «Жіноче лідерство та підприємництво» Інститут партнерства та сталого розвитку. Institute of Partnership and Sustainable Development : веб-сайт. URL : http://ipsd.org.ua/_(дата звернення: 22.08.2020). 
16. Жіноче підприємництво в Україні. WoMo : веб-сайт. URL : https://womo.ua/zhinoche-pidpriyemnitstvo-v-ukrayini-64-opitanih-vlasnits-biznesugotovi-do-hocha-b-chastkovogo-perehodu-v-onlayn-85-pragnut-dodatkovogonavchannya/ (дата звернення: 22.08.2020). 